\title{
AN EVALUATION OF LARGE-SCALE RETAILING WITH EMPHASIS ON THE CHAIN STORE
}

\author{
Charles F. Phillirs*
}

\section{Some Reasons for Large-Scale Retailing}

Retailing has become increasingly large-scale ${ }^{1}$ for reasons similar to those explaining the development of large-scale manufacturing. ${ }^{2}$ First, certain factors make it possible for the larger retailer to undersell smaller retailers. Second, the larger retailers have brought about improvements in retailing practices from the consumer's point of view. Third, large-scale retailing has been profitable, thus attracting capital and management.

\section{Ability to Undersell: Economies}

The ability of the large-scale retailer to undersell competitors arises from the economies which he has been able to effect, his willingness to accept a relatively low profit margin per dollar of sales, and-except in the case of the department storehis ability to limit "free" services and still attract customers. While by no means all the economies of large-scale retailing can be considered here, an understanding of a few of them is essential to an evaluation of large retailers.

( $I$ ) The influence of integration in reducing the cost of the large-scale retailer can be set forth by means of a simple illustration. In the grocery field the typical wholesaler contacts the independent retailer through a number of salesmen. Because the retailer (a) splits his business among a number of wholesalers, (b) orders frequently, and (c) has small weekly sales, the salesmen of each wholesaler have to make frequent calls on each retailer and be contented with small orders. Not only does this lead to a high selling cost, it also raises the cost of billing, credit extension and collection, and delivery. Because of frequent "fill in" orders, the wholesaler finds it difficult to maintain a regular and economically laid out delivery schedule.

* A.B., I93I, Colgate University; Ph.D., 1934, Harvard University. Professor of Economics, Colgate University. Author, Marketing (I938). Member Editorial Board, Journat of Marketino. Contributor to Harvard Business Review, Journal of Business of the University of Chucago, American ECoNOMIC REview, and other periodicals.

${ }^{I}$ Any division of retailers into large and small is arbitrary. For purposes of this article chain stores, department stores, and mail-order companies will be considered as the main forms of large-scale retailing. In 1935 these retailers did $32.9 \%$ of all retail business. If independent supermarkets are considered as large-scale retailers, the foregoing ratios would be slightly increased; but as Census data are not yet available for such operators an all-over ratio cannot be given.

'One basic difference: more of the economies of large-scale manufacturing arise from the use of machinery. 
In contrast, the units of a grocery chain concentrate practically all their purchases from a single chain-operated warehouse. No salesmen are necessary; headquarters provides the store manager with an order blank for his weekly order and requires that it shall be at the warehouse by a certain time. Delivery routes can be laid out to achieve the greatest economy while the size of the individual order reduces clerical and assemblying cost per dollar of goods delivered. Although it is contrary to popular opinion, Professor McNair is perfectly correct in stating that "integration of functions rather than large buying power is the principal source of chain store economies."3

(2) In the small store, specialization cannot be carried very far. Frequently the proprietor serves as buyer, salesman, bookkeeper, credit manager, advertising manager, and janitor. If he devotes adequate time to buying, some other function is neglected. But the large-scale retailer is able to place each activity in the hands of a specialist. In the department store, for example, a fourfold classification of acitivities is usual, with an executive in charge of each major activity. A store manager keeps the store's physical plant in condition, provides an adequate delivery system, secures personnel, and so on. The controller oversees the store's finances, accounting, and extension of credit. There is a publicity manager to handle all promotional efforts. Finally, the general merchandise manager is in charge of actual buying and selling activities. Of course, in the department store of any size, each of the foregoing specialists is assisted by a number of others. To illustrate, the store manager is assisted by a personnel director, a traffic manager, a head receiving clerk, and so on.

(3) While the possession of progressive management $t^{4}$ may not be an inherent advantage of large-scale retailers, certainly in practice such management is far more characteristic of the large than of the small retailer. In part, this situation is a result of the fact that large retailers are merely the best of the small retailers grown up. The progressive management of large retailers is reflected in many factors. In many department stores it has led to the setting up of expense and merchandise budgets as guides for future operation. It is evidenced by a high rate of merchandise turnover in chain stores of various kinds. In the mail-order firms it is reflected in the adaptation of mail-order selling to modern conditions-through mail-order offices, overnight delivery systems, and more accurate word and picture descriptions of merchandise.

(4) Closely associated with progressive management is the large retailer's ability to engage in research. In fact, the research department of many retail organizations is looked upon as an arm of management. The store's customers may be studied in order that services and goods offered may be more in keeping with what they

${ }^{3}$ McNair, Marketing Functions and Costs and the Robinson-Patman Act (r937) 4 LAW \& CoNTEMP. Pros. 343. If a specific illustration is desired, consider the fact that the A. \& $P$. can market a $\$ 3.00$ box of oranges from a California shipping point to a metropolitan New York store for 12 cents (exclusive of freight) as against 46 cents for non-integrated marketers. Grocery Executive's edition of (June 1940) Chain Store Age 52.

'On this topic, of. Taylor, Progressive Retail Management (May 1940) 209 AnNals 46. 
want. Aid may be given the real estate department in selecting suitable locations. Competitors' prices may be analyzed so that management will know its competitive position. For the small retailer the expense of a research department precludes its development, while the proprietor's absorption with other activities prevents him from doing very much himself along these lines.

(5) Buying merchandise in quantities is not a major advantage of all large-scale retailers. Many departments even in large department stores have sales volumes no larger than those achieved by independent limited-line stores. On the other hand, the chain store and the mail-order house can and do buy merchandise in quantities. Partly because such buying enables a manufacturer to effect economies and partly because it puts the retailer in a position to demand that he share in the savings, important quantity discounts are obtained. In addition, quantity buying is practiced as regards store equipment and fixtures, thus enabling the chain-store company to equip a number of units at a lower cost per unit than is possible for the independent.

Closely connected with quantity buying of merchandise and equipment is the large-scale retailer's ability to "buy" money for less. Of course, this ability to borrow money at a lower interest rate is only partly a result of the amounts he borrows; even more responsible is the fact that bankers and investors look upon the large-scale retailer as a better risk than the small retailer.

\section{Ability to Undersell: Low Profit Margin}

There is evidence, in certain fields at least, that large-scale retailers operate on a smaller net profit margin than their small-scale competitors. By way of illustration, Professor Vaile presents figures indicating a profit margin of 1.06 percent of sales for grocery chains, as against $I .96$ percent for independent wholesalers and retailers combined, and 4.4 percent for voluntary chains. ${ }^{5}$

It should not be thought that the acceptance of a low profit margin decreases the total profits of large-scale retailers. Quite the contraryl What large-scale retailers are trying to do is to maximize their profits by taking a low net profit margin on a large volume of sales, rather than a large margin on smaller sales. This policy enables the large retailer to quote lower prices to the consumer.

\section{Ability to Undersell: Limitation of Services}

Some large-scale retailers, especially chain stores, have increased their ability to undersell some small-scale competitors by limiting the services performed. The majority of the chain stores sell on a cash and carry basis while, in some fields, they are placing their stores on a self-service basis. In the department stores operated by Sears, Roebuck and Company and Montgomery Ward the returned-goods privilege is restricted as compared with many small specialty shops.

Limitation of service on the part of the chain is not, of course, an inherent advantage; it can be done by any retailer as, for example, the independent supermarket.

\footnotetext{
${ }^{8}$ Statement by Roland S. Vaile, Hearings before the Subcommittee of the Committee on Ways and Means on H. R. I, 76th Cong., Ist Sess. (I940) I4. Mimeographed.
} 
But the chain, because of more progressive management, has been able to take the initiative in devising ways of limiting costly services, and still attract customers. In contrast, the large department stores have gradually increased the services which they offer to the consumer.

\section{Prices of Large and Small Retailers}

Unfortunately the evidence on prices asked by large and small retailers is limited to chain and independent stores, and especially to those in the grocery and drug fields. But that available does indicate that the economies of the chain store, its lower net profit margin, and its limitation on services have given it a substantial price advantage. A few years ago a Federal Trade Commission investigation put independent grocery store prices 8.5 percent in excess of chain store prices, and independent drug store prices 20.67 percent in excess of prices on comparable merchandise in chain stores. ${ }^{\circ}$ At the end of 1939, John A. Hartford, president of the A \& P, stated that prices in service grocery chains were 8 percent below prices in independent stores, while chain supermarket prices were an additional 8 percent lower. ${ }^{7}$ A study conducted in 1935 in Florida found the chains underselling independents in the dry-goods and furnishings field from 3.I to 17.8 percent, depending on the size of the chain, while on a small number of automobile accessory items the chain advantage was from I0.6 to 24.2 percent. $^{8}$ In view of these lower prices, it is not difficult to understand why, in a society such as ours where the average family has less than $\$$ r 300 a year to spend on consumption items, consumers have sought out the large-scale retailers.

It is impossible at present to indicate exactly how much of the chain's price advantage is a result of each of the three factors making it possible. However, we may indicate that, contrary to popular opinion, the chain's low prices are not mainly a result of a lower cost of merchandise. Analysis of the Federal Trade Commission's figures reveals that but 16.4 percent of the grocery independents' high prices were a result of a greater cost of merchandise, while the comparable figure in the drug field was 8.8 percent. As the chain's advantage in a lower net profit margin cannot be great, it is evident that the main cause of its lower prices lies in its ability to operate for less than does the independent.

\section{Improved Retailing Practices from the Consumer's Point of View}

Integration, specialization, progressive management, and research have enabled large-scale retailers to do more than merely undersell competitors, important as such underselling may be. It should be emphasized that these factors have been equally important in enabling such retailers to improve on certain retailing practices, with the result that consumers are better served. This better service is evident in depart-

- Phillips, The Federal Trade Commission's Chain Store Intrestigation: A Note (1938) 2 J. Marketing 19r. As a result, at least in part, of fair trade laws, the drug chains' present-day advantage is less than that indicated by this study.

Tood Field Reporter, Jan. 8, 1940.

- Beckman and Nolen, The Chain Store Problem (1938) 132. 
ment stores where many "free" services have been added, but it is also important in chain store operation. For example, compare and contrast the average chain and independent grocery store. From external appearances the chain unit is more attractive, both in store front and in window display. Inside, its fixtures are more modern, its displays more attractive, and it gives the impression of greater cleanliness. Because of its standardized ordering routine, goods are less frequently out of stock.

Increasingly, large-scale retailers are adopting other practices as a means of attracting customers. Some of them are establishing merchandise testing bureaus so that they can offer merchandise which is better fitted to the needs of their customers. They are grade-labeling some of their merchandise. Locations are being selected with greater skill so as to be more conveniently placed for larger numbers of customers. Employee training programs seek to raise the caliber of the employee of the large organization. Both mail-order houses and department stores offer customers still another service which cannot be offered by the small retailer-a large variety of merchandise which can be purchased from a single source. For example, Montgomery Ward carries about 150,000 items in its general catalogue, some of which are not stocked by a single small retailer in many small towns.

Perhaps it should also be mentioned that large retailers sometimes take the lead, not only in reducing prices on an article, but also in having the article redesigned for greater consumer value. By way of illustration, consider what has happened in the production and marketing of the electric refrigerator. ${ }^{\circ}$ Realizing that many customers were dissatisfied with the small boxes which manufacturers were producing to sell at moderate prices, in 1934 a leading mail-order house brought out a private brand box with six cubic feet of space and sold it for what three and a half and four cubic feet boxes were bringing through other retailers. The public responded to such a degree that this mail-order company became one of the country's three largest distributors of electric refrigerators. Old-line manufacturers were forced to follow its lead. While small-scale retailers might have sensed the demand for the larger, moderate-priced box and while eventually the manufacturers themselves would have developed such a box, only a large-scale retailer could take the initiative in speeding up this change in merchandising policy on the part of the manufacturers.

\section{Large Profits}

Even with advantages to offer the consumer, large-scale retailing would not have developed if profits had proven insufficient to attract capital and management to the field. While space is not available for the presentation of detailed statistical evidence, a study of the annual reports of large retailers will convince one that profits have been attractive. In spite of intense competition which the growth of the selfservice store has brought to the food field, thirteen grocery chains in 1939 reported net

\footnotetext{
- Nourse and Drury, Industrial Price Polictes and Economic Progress (1938) 108-109.
} 
profit before interest of II.65 percent on invested capital. During the same year ten variety chains had net profits of $I 3.4$ percent and six mail-order companies of $I 6.66$ percent. ${ }^{10}$ By no means was 1939 the most profitable year for large-scale retailing.

\section{Agrtation Against Large-Scale Retailing}

It is instructive to note that, in spite of the advantages which they have to offer, each type of large-scale retailer has faced organized opposition. ${ }^{11}$ While the department store and the mail-order house survived the attacks aimed at them, the movement against the chain store gives promise of more telling effects. As a matter of fact, the small-scale retailer has much more to fear from the chain store than from any other type of large retailer. While the mail-order house has certain advantages, it is doubtful if conditions are such that it will develop greatly in the future. ${ }^{12}$ The large department store faces certain difficulties in trying to draw customers from a wide area to a single store, and these difficulties increase as cities spread out. But the situation is different with a chain-store organization. Instead of trying to draw people to a single store, it makes use of the size stores best fitted for profitable operation and places them near to the customers.

In view of the greater long-run significance of the chain store threat, as well as the fact that agitation against the chain is playing such an important part in retailing today, the following paragraphs will be limited to an examination of the anti-chainstore position. With some changes, a similar case has been made out for opposing other large-scale retailers. Basically, the case for governmental interference with the chain store rests upon four propositions, each of which will be stated and subjected to a brief analysis.

\section{Chain Stores Use Unfair Competitive Tactics}

The particular practices of the chain stores which are now usually considered as unfair center around the chain's pricing of merchandise. ${ }^{13}$ It is claimed that chain stores use loss leaders, that is, merchandise priced unreasonably low, as a means of attracting customers. To this complaint, two facts are pertinent. First, unless customers are attracted by a loss-leader policy into a store which has a relatively high average price, this policy is not harmful to the customer. As we have seen, chain stores have relatively low prices. Second, independent retailers can and do engage in the use of loss leaders. Professor Vaile, basing his opinion on studies of the retail

${ }^{10}$ Securities and Exchange Commission data: Census of American Listed Corporations (1939) Report 13, Supp. 19, at 14; Report 14, Supp. II, at 9; Report 17, Supp. I6, at 9.

11 The history of this opposition is given in Gould, Legislative Intervention in the Confict Between Orthodox and Direct-Selling Distribution Channels; Feldman, Legislative Opposition to Chain Stores and Its Minimization, both supra this issue.

${ }^{12}$ For discussion, see Phillips, Marketing (1938) 373-378.

${ }^{18} \mathrm{~A}$ few years ago the chains were said to give light weights and to shortchange customers. However, studies of these practices have demonstrated the invalidity of such charges. See Fed. TRADE Commission, Chain Stores: Short-Weighting and Over-Weighting in Chain and Independent Grocery Stores (1933); Taylor, A Study of Weights in Chain and Independent Grocery Stores in Durham, North Carolina (I93I) 9 Harv. Bus. Rev. 443. 
trade in Minnesota, feels "that independent stores use loss leaders as frequently as do chain stores."14

It should be pointed out, however, that chain stores are in a particularly good position for making use of loss leaders. By rotating leaders among stores in various sections, the chain always has some stores turning in "normal" profits while others are establishing a reputation for low prices. ${ }^{15}$ In contrast, deep-cut prices on the part of the independent may substantially reduce his net profit in the only store from which it is obtained.

\section{Chain Stores Are Unfair to Their Employees}

Chain stores are deemed unfair to their employees in that they require long hours of work, pay low wages, encourage dishonest practices, and offer little chance of advancement. On none of these points is the evidence conclusive. As regards working hours, it is the writer's opinion that chain store hours are certainly no longerand they may be somewhat shorter-than those required in competing independent stores. Studies of chain and independent wages are in conflict; a Federal Trade Commission investigation gives the advantage to the independent, ${ }^{16}$ while Census data are favorable to the chain store. ${ }^{17}$ As a matter of fact, because the greater specialization in the chain store allows it to make use of some employees with relatively low abilities, it is doubtul if statistics of chain and independent wages are comparable enough to have any validity. It seems logical that either the chain or the independent would face difficulties in holding employees receiving less than the comparable employees of other stores.

The charge that chain stores encourage their employees to be dishonest probably has little foundation. It arose out of the policy of charging all merchandise to the stores at the retail price. As some shrinkage is inevitable, because of theft and spoilage, some persons maintained that the manager would have to cheat the customer to make up the shrinkage, or show an inventory shortage which would jeopardize his position. Such is not the case. Because shrinkage is inevitable, allowance is made for it and only an abnormal shrinkage causes the personnel department to look with suspicion upon a manager. Actually, it is somewhat difficult to imagine a person being more dishonest merely to hold his job than he would be as an independent proprietor when dishonesty might be reflected in an immediate increase in his profits.

Unfortunately, many chain store employees will never advance very far; and even more unfortunate, because more persons are involved, is the fact that this same statement is true of employees in independent stores. The plain fact is that retailing employs a large number of persons whose abilities do not fit them for any great promotion. But for the able employee, attractive advancement opportunities are available in chain organizations. Managers of small stores may advance to managerships

14 Hearings, supra note 5, at 16.

${ }^{15}$ For a discussion of pricing by food chains, see Phillips, Price Policies of Food Chains (1941) 19 Harv. Bus. REv. 377 .

${ }^{16}$ Fed. Trade Commission, Chain-Stores: Chatn Store Wages (1933) i7-21.

${ }^{17}$ Retail Distribution, in I Census of Businesss 1935 (U. S. Dep't Com. 1937) 2-13. 
in large stores, or become superintendents, district managers, buyers at headquarters, and so on. Even managerships in the larger chain units frequently give an annual return in excess of $\$ 10,000$.

\section{Chain Stores Drive Independent Retailers Out of Business}

This claim has several aspects. First, complaint is registered against the methods used by the chain; that is, that chains force independents out by means of loss leaders, underweighting, and low wages. Second, it is suggested that small retailers are socially more desirable than large retailers, so that all large-scale retailers are to be opposed. Third, and finally, fear has been expressed that all small-scale retailers will be driven out of business, thus leaving large retailers in a monopolistic position. The first of these three aspects has been examined in preceding sections and, in the main, found wanting, while the third will be treated in the following section. It is with the second aspect that we are now interested.

Small retailers are deemed preferable to large-scale retailers because it is felt that the chain store represents absentee ownership, taking little interest in the progress of the communities in which it operates. Managers are transferred frequently so that they do not have time to become assets to the locality. By drawing off profits to headquarters, the chain drains money out of the community so that it becomes diffcult to keep the town prosperous. By various devices, especially a rapid stock turnover, chains are said to avoid their share of taxes.

We have enough information to give definite answers on some of these issues. Studies indicate that chain stores actually pay heavier taxes than do independents. ${ }^{18}$ While money profits are transferred out of town, it must be remembered that in an exchange economy such as ours the main purpose of money is to serve as a medium of exchange. As long as the community gains by the exchange there is no reason for complaint; that it does gain in some degree is indicated by the fact that the chain's price advantage is greater than its net profit margin.

The answer to the charge that the chain's absentee ownership is socially undesirable must be somewhat indefinite as we have no exact test of just what is socially desirable. Yet it is important to note that many chains are taking steps to build themselves into community life. Managers are being encouraged to join local clubs and to become active in them. A certain percentage of the sales of each store is put at the disposal of the manager to be contributed to worthy local activities. Of course, many chains are still far from being as good "citizens" as is desirable, but we should not overlook the fact that by no means are all independent merchants the community-minded men they are sometimes pictured.

Even though the statement may sound harsh, we need to understand that many small independent retailers probably deserve to fail. In 1935, 44.5 percent of all independent stores had sales of less than $\$ 5,000$ and 64 percent of less than $\$ 10,000 .^{19}$

\footnotetext{
${ }^{18}$ Fish, Comparative Chain and Independent Store Taxation in Nine Western States (1939) 24 Buzl. Nat. Tax Ass's 275.

${ }^{10}$ Retail Distribution, supra note $\mathrm{I} \%$, at $\mathrm{x}-3 \mathrm{r}$.
} 
In stores so small the owner can barely eke out a living. While some of them are in the hands of efficient operators who will gradually expand them into larger units or are in fields where very small retailers are desirable, the majority of them are ineffectively operated and their relatively high prices are a burden to society. As one travels around the country and observes small stores, his wonder is not that so many of them fail, but that so many of them are able to remain in business. Perhaps Professor Taylor does not overstate the matter when he writes: ${ }^{20}$

The only conclusion that one can draw from the statistical evidence now available is that the average independent retailer is incompetent and inefficient and that his continuance in a business which is unprofitable to himself constitutes a serious economic problem.

Perhaps it is time we begin to think about saving the consumer from the cost of supporting a host of small retailers!

Popular opinion to the contrary, the development of the chain store has not increased the rate at which small independents fail. Several studies substantiate this conclusion. To cite but one of them: ${ }^{21}$

The life of the independent retailer was as precarious before the day of the chain store as at present. And some types of enterprise where competition of the chain store is not a factor ... have a higher mortality than those ... where chain-store competition is most acute. Consequently elimination of the chain store is not the indicated remedy.

The simple fact is that the high mortality is the price of a laissez-faire system; and any attempt to assist the small independents by suppressing their larger competitors is apt to decrease the average life of retail concerns as a whole without increasing the lives of the independents it is intended to protect.

While it is true that chain stores are now doing a substantial volume of business which might otherwise be transacted by independent retailers, it seems likely that independents would be failing as rapidly as today if there were no chain stores. So many independent stores are so poorly managed as to be unable to compete even with the better-operated independents. It is doubtful if the displacement of many of these poorly-managed independent stores by chain stores is opposed to social welfare.

\section{Chain Stores Are Monopolistic}

Isn't there a likelihood that the replacement of independents by chain stores may go so far that no independents are left? Under such circumstances would not the chains be in a position to take monopoly profits by raising prices? The answers to both of these questions, as the following discussion will indicate, are in the negative.

Those who worry about the chains driving all independents out of business fail to consider the advantages which accompany independent operation. Personal contact of proprietor with his customers gives him an opportunity to build his stock and services to meet the needs of the customers involved. Personal contact with

\footnotetext{
${ }^{20}$ Taylor, supra note 4 , at 47 .

${ }^{21}$ Hutchinson, Hutchinson and Newcomber, $A$ Study in Business Mortality (1938) 28 AM. EcoN. REv. 497,514 .
} 
employees enables him to build a loyal organization. All decisions are made within the store so that they can be made quickly. While the independent may be undersold, the importance of non-price competitive elements suggests that by no means will all customers desert him. In spite of chain competition, the independent retailer still dominates practically all retail fields. ${ }^{22}$ Moreover, independents are still finding it possible to enter retailing and compete with the chains. ${ }^{23}$ In fact many of them are competing so successfully that they are developing small chains of their own. ${ }^{24}$ As long as the chance of successful entry into retailing remains open, chain stores can never drive all independents out of the field.

We can go even further than is suggested by the preceding paragraph. There are factors other than the advantages of the independent retailer which indicate that, even in the absence of governmental regulation, the chain store will find it difficult to increase its percentage of total retail business. Many independent retailers have adopted better retailing practices and have joined together to effect joint buying, advertising, and other merchandising activities. Some of them are meeting chain store competition through the establishment of supermarkets. Consumers' co-operatives are growing and may prove to be a competitive element retarding chain store growth. Many customers do not like the standardization which characterizes the chain store. As chains grow in size, personnel and managerial difficulties become greater. There is evidence that even the chain's price advantage over the independent does not increase in proportion to the size of the chain. ${ }^{25}$ The profit margin in chain store operation was falling long before $1929 .{ }^{26}$ This decline will be a factor in slowing up the expansion of existing chains and in making the field less attractive to outside capital. Finally, it must not be overlooked that interchain competition is of increasing importance, and would exist even in the absence of independent retailers. ${ }^{2 \pi}$

\section{Some Conclustons}

The preceding paragraphs have suggested that large-scale retailing has certain advantages to offer the consumer which, in practice, cannot be offered by small independents. In view of the low incomes of the majority of consumers, it seems doubtful if the alleged evils of the chain store are sufficient to justify restrictions of the types which have been imposed upon them during the last decade. It has also

${ }^{22}$ In 1935 , in but one (variety) of 25 retail fields did the independent do less than ro percent of all business. In three fields his ratio was $40-49.9 \%$, in one $50-59.9 \%$, in three $60-69.9 \%$, in nine $70-79.9 \%$, and in eight in excess of $80 \%$. Retail Distribution, supra note 17 , at I-24.

${ }^{23}$ Between 1929 and 1935 the number of independents increased by nearly 100,000 while the number of chain units fell by 20,000. See Census data summarized in Philitips, Marketting (1938) 363,437 .

24 For example, see Phillips, Why Laws to Aid Small Stores are Unnecessary (Dec. 2, 1937) PRINTERs' INK 13, 82.

${ }^{25}$ Phillips, An Economic Analysis of the Supreme Court's Decisions on Chain Store Taxation (1938) II J. Bus. Unrv, CH. 51, 62-63.

${ }_{30}$ The Federal Trade Commission reports the following profit-to-sales ratios for chains in a number of fields: $1919,7 \% ; 1922,6.4 \% ; 1925,5.6 \% ; 1927,4.8 \% ; 1928,4.6 \% ; 1929,4.1 \%$; and $1930,2.9 \%$. Chain-Stores: Sales, Costs, and Profits of Chatn Stores (i933) 28, 29, 3 I.

${ }^{37}$ With the above analysis compare the position taken by Wolff, Monopolistic Competition in Distribution, supra this issue. 
been suggested that there are a number of factors which will tend to limit chain store growth, even in the absence of legislation. It might be added that, if future experience should demonstrate that the chains are paying wages or exacting hours of labor that are felt to be socially undesirable, legislation aimed directly at these matters is more acceptable than chain store taxation. Such specific legislation would correct the situation without, as is inevitable with chain store taxes, penalizing innocent chain store operators and raising prices to the consumer.

Unless resort is had to legislation, retailers best meeting consumer demand will continue to replace those less able to satisfy it. This is the basic law which has been exemplified in the growth of the chain store. If we really want to keep retailing in the hands of independent merchants, perhaps we should begin to aid the independent to become a better merchant. Such an approach, if successful, would do more than keep the independent-it would also make for greater efficiency in marketing. Of course, the chain store tax approach, carried far enough, will keep the independent, but it will do nothing to increase efficiency in retailing. In fact, chain store taxes tend to make less efficient a field which already gives evidence of harboring a vast amount of inefficiency. ${ }^{28}$

\footnotetext{
${ }^{28}$ Stewart and Dewhurst, Does Distrubution Cost Too Much? (1939) 320-325.
} 